9. Guidelines 3/2018 on the territorial scope of the GDPR(Article 3) - Version for public consultation. URL: https://edpb.europa.eu/sites/edpb/files/files/file1/edpb_guidelines_3_2018_ territorial_scope_en.pdf.

10.М. Ковінько. Екстратериторіальна дія GDPR: ризики для українців та практичні рекомендації для уряду. «Молодий вчений» № 4 (68) квітень, 2019 р., с. 371-374. URL: http://molodyvcheny.in.ua/files/journal/2019/4/83.pdf.

11. Extraterritorial Application of The GDPR. URL: https://www.jdsupra.com/legalnews/ extraterritorial-application-of-the-gdpr-25522/.

12. Adèle Azzi, 'The Challenges Faced by the Extraterritorial Scope of the General Data Protection Regulation', 9 JIPITEC 126 (2018). URL: https://opencasebook.org/casebooks/104360-internet-platforms-gdpr-and-ip-enforcement-ceipi-advanced-training-2018/ resources/6.1.7-adele-azzi-the-challenges-faced-by-the-extraterritorial-scope-of-the-general-data-protection-regulation-9-jipitec-126-2018\#/.

КАНТОР Н. Ю., старший викладач кафедри правознавства, соціології та політології (Дрогобицького державного педагогічного університету імені Івана Франка)

УДК 342.9 (477)

DOI https://doi.org/10.32842/2078-3736-2019-6-1-5

\title{
СУМІРНІСТЬ ЗАГАЛЬНИХ ЗАСАД СУДОЧИНСТВА І ПРИНЦИПІВ МЕДІАЦІЇ
}

У статті досліджено проблему сумірності загальних засад судочинства та принципів медіації. Як суміжні правові інститути, судочинство та медіація характеризуються низкою спільних ознак, водночас є між ними і суттєві відмінності. Важливу роль у функціонуванні цих інститутів відіграє система принципів, як фундамент побудови будь-якого правового механізму розв'язання спорів. Підтверджено, що система основних засад судочинства відображена в Конституції України, Законі України «Про судоустрій і статус суддів» та галузевому процесуальному законодавстві. У принципах судочинства в найбільш концентрованому вигляді втілюються правова природа і завдання судової влади в Україні. Установлено, що нормативне закріплення системи принципів медіації відсутнє, як і нормативно-правова база медіації загалом. Доведено, що відсутність нормативного вираження принципів медіації не може бути перешкодою для функціонування цього інституту. Проаналізовано поширені в юридичній науці підходи до класифікації принципів медіації. Виокремлено загальноправові, галузеві/міжгалузеві та спеціальні принципи медіації. Загальноправові принципи виступають основою обох правових інститутів - і судочинства, і медіації - і забезпечують їх сумірність. Галузеві принципи характеризують присудову медіацію, наприклад, досудове врегулювання цивільних спорів за участю судді певною мірою підпорядковане принципам цивільного судочинства. До спеціальних принципів належать доступність, добровільність, рівність сторін, нейтральність медіатора, конфіденційність. Такі принципи виокремлені на основі узагальнення зарубіжного досвіду та аналізу рамкових міжнародних

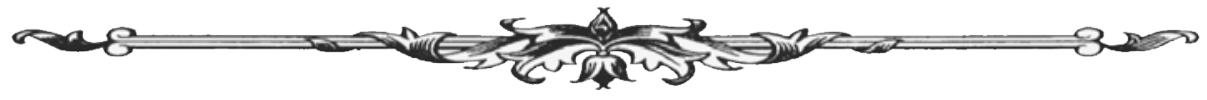


документів у сфері медіації. Сформульовано визначення принципів медіації це засади, які формують основу процедури медіації і забезпечують ефективне й взаємоприйнятне розв'язання конфлікту самими його сторонами за участю нейтральної особи - медіатора.

Ключові слова: альтернативне врегулювання спорів, медіація, принципи медіачії, присудова медіація, загальні засади судочинства.

The article studies the problem of the commensurability of the general principles of legal proceedings and the principles of mediation. Being related legal institutions, legal proceedings and mediation are characterized by a number of common features, and at the same time they have significant differences between them. The system of principles plays an important role in the functioning of these institutions being the foundation for building any legal mechanism for resolving disputes. It is confirmed that the system of basic principles of legal proceedings is reflected in the Constitution of Ukraine, the Law of Ukraine "On the Judicial System and the Status of Judges" and sectoral procedural legislation. The legal nature and tasks of the judiciary in Ukraine are embodied in the principles of legal proceedings in the most concentrated form. It is established that the normative consolidation of the system of principles of mediation is absent as well as the regulatory framework of mediation as a whole. However, it is proved that the lack of a normative expression of the principles of mediation cannot serve as an obstacle to functioning of this institution. The author analyzes approaches to the classification of mediation principles that are common in legal science highlighting general legal, sectoral/intersectoral and special principles of mediation. General legal principles form the basis of both legal institutions - legal proceedings and mediation and ensure their commensurability. Sectoral principles characterize prejudicial mediation, for example, pre-trial regulation of civil disputes with the participation of a judge is subordinated to a certain extent to the principles of civil proceedings. The special principles include accessibility, voluntariness, equality of parties, neutrality of the mediator, and confidentiality. Such principles are highlighted on the basis of a synthesis of foreign practices and analysis of international documents in the field of mediation. The author formulates the principles of mediation - these are the principles that form the basis of the mediation procedure and provide effective and mutually acceptable resolution of the conflict by its parties with the participation of a neutral mediator.

Key words: alternative dispute resolution, mediation, principles of mediation, prejudicial mediation, general principles of legal proceedings.

Постановка проблеми. Медіація, що являє собою один із альтернативних способів урегулювання спорів, рекомендована до впровадження на рівні Ради Європи та ЄС. Однак в Україні медіація позбавлена законодавчої бази, хоч ії переваги перед судовим способом розв'язання спорів (конфліктів) визнають і науковці, і практики. У зв'язку з цим проблеми медіації та їі співвідношення із судочинством не втрачають актуальності.

Аналіз досліджень. Вітчизняна юридична наука, услід зарубіжній, нині приділяє пильну увагу медіації. Останніми роками в Україні з'явилася низка грунтовних досліджень проблем медіації, при цьому науковці не оминають увагою питання про правову природу принципів медіації, їх зміст, класифікацію тощо (Н. В. Боженко, 3. В. Красіловська, Ю. Д. Притика). У багатьох роботах вітчизняних учених висвітлюється як загальна проблематика принципів права (О. Грищук, О. В. Зайчук), так і система основних засад судочинства в Україні (В. В. Городовенко, Р. В. Міліціанов та ін.). Але питання про сумірність принципів медіації та загальних засад судочинства потребують окремого дослідження.

Метою статті $\epsilon$ аналіз співвідношення основних засад судочинства та принципів медіації, що виступають фундаментом цих суміжних правових інститутів.

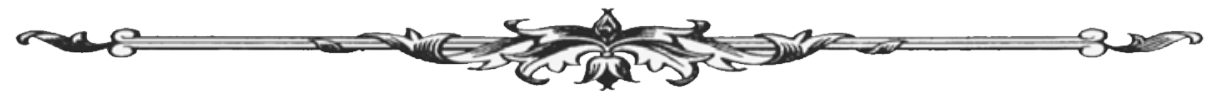


Виклад основного матеріалу. Твердження про те, що судочинство та медіація являють собою суміжні правові інститути, уже не оспорюється у сучасній юридичній науці. Понад те, висловлюється думка, що медіація (зовнішнє спонукання сторін до примирення) безпосередньо пов'язана із розвитком самої судової системи. Науковці наполягають на первинній природі третейських судів порівняно 3 державним судочинством. Третейські суди інакше називали «полюбовними», тобто у самій назві спостерігався примирний характер вирішення спору (Запара, 2015: 86). Хоч і медіація, і судочинство виконують однакову функцію - усунення приватно-правових та публічно-правових спорів (конфліктів), між ними $\epsilon$ певні відмінності, які, передовсім, зумовлені нетотожністю їх фундаментальної основи, якою виступає система загальних засад (принципів) кожного із цих правових інститутів.

Роль принципів права полягає в тому, що саме через них, на думку О. Грищук, відбувається впровадження загальновизнаних соціальних цінностей у життя, їхня реалізація та застосування у правовій діяльності (Грищук, 2015: 16).

Як справедливо твердить Ю. Д. Притика, система принципів виступає наріжним каменем побудови будь-якого правового механізму розв'язання правових конфліктів, чи державного (у формі здійснення правосуддя), чи альтернативних способів, куди, зокрема, відноситься і медіація (Притика, 2010: 87).

Згідно зі ст. 124 Конституції України, юрисдикція судів поширюється на будь-який юридичний спір та будь-яке кримінальне обвинувачення. У передбачених законом випадках суди розглядають також інші справи (Конституція України: ст. 124). Конституційний принцип поширення юрисдикції судів на будь-який юридичний спір корелює 3 положеннями ст. 6 Конвенції про захист прав та основоположних свобод людини, відповідно до якої кожен має право на справедливий і публічний розгляд його справи впродовж розумного строку незалежним і безстороннім судом, установленим законом (ЄКПЛ: ст. 6). Водночас Основний Закон гарантує не лише судовий захист прав і свобод, а також право кожного будь-якими не забороненими законом засобами захищати свої права і свободи від порушень і протиправних посягань (Конституція України, 1996: ст. 55). 3 цієї конституційної норми випливає, що таким способом може бути медіація, щоправда, Україні вона поки що не отримала необхідної нормативно-правової бази. Відповідно не можна й говорити про нормативне закріплення системи принципів, на яких вона базується. I навпаки, принципи судочинства чітко регламентовані законом. Так, у ч. 3 ст. 129 Конституції України визначаються основні засади судочинства, що за своєю юридичною сутністю розглядаються як його конституційні, міжгалузеві принципи, які мають фундаментальний характер для різних видів судочинства (Теліпко, 2011: 404).

Окрім імперативного припису про те, що суддя, здійснюючи правосуддя, є незалежним та керується верховенством права, ст. 129 закріплює такі засади судочинства: 1) рівність усіх учасників судового процесу перед законом і судом; 2) забезпечення доведеності вини; 3) змагальність сторін та свобода в наданні ними суду своїх доказів і у доведенні перед судом їх переконливості; 4) підтримання публічного обвинувачення в суді прокурором; 5) забезпечення обвинуваченому права на захист; 6) гласність судового процесу та його повне фіксування технічними засобами; 7) розумні строки розгляду справи судом; 8) забезпечення права на апеляційний перегляд справи та у визначених законом випадках - на касаційне оскарження судового рішення; 9) обов'язковість судового рішення.

Загалом, як вірно вважає А. Городовенко, правова природа і завдання судової влади розкриваються не у формі прямого закріплення в конституційному тексті компетенції конкретних органів, а шляхом формулювання принципів судової влади, які характеризують як організаційний, так і процесуальний аспекти ііі функціонування (Городовенко, 2018: 75).

Крім того, принципи судочинства закріплює Закон України «Про судоустрій і статус суддів» (Про судоустрій і статус суддів, 2016: ст.ст. 5-15); галузевим законодавством визначаються засади судочинства в судах різних юрисдикцій. Так, наприклад, загальні засади кримінального провадження, закріплені главою 2 Кримінального процесуального кодексу України, «служать гарантією правосуддя, забезпечення прав і свобод людини, законних інтересів фізичних і юридичних осіб» (Бандурка та ін. 2012: 17).

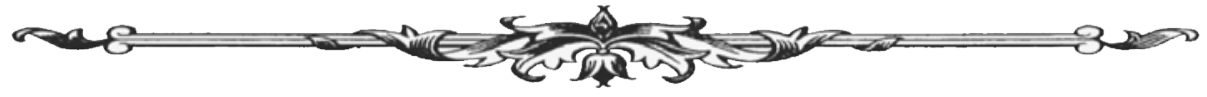


За результатами класифікації конституційних засад судочинства в Україні Р.В. Міліціанов цілком слушно характеризує засади судочинства як норми прямої дії, що мають безперервний, стабільний, виключний, юрисдикційний, гарантійний, забезпечувальний, базисний, системний, стабілізуючий характер (Міліціанов, 2014: 111).

Звичайно, закріплення на рівні Основного Закону держави фундаментальних засад судочинства забезпечує ефективне виконання поставлених перед судовою владою завдань. Однак відсутність нормативного вираження принципів медіації $\epsilon$ не перешкодою для функціонування цього інституту, бо «регулюючий вплив на правозастосовну практику можуть чинити і такі правові ідеї-принципи, які не закріплені в законі» (Зайчук, 2012: 23), тобто зміст принципу значно ширший за його законодавчий вираз.

Серед вітчизняних науковців немає одностайності щодо розуміння принципів медіації та їх класифікації. Окремі дослідники розмежовують принципи поведінки медіатора і принципи медіаційної процедури (Красіловська, 2017: 33). Нам імпонує підхід Ю. Д. Притики, який умовно поділяє принципи медіації на загальноправові, міжгалузеві та конкретно-правові (Притика, 2010: 88). До першої групи традиційно зараховують принципи демократизму, гуманізму, соціальної справедливості, законності, єдності прав та обов'язків, поєднання примусу та переконання, невід'ємності природних прав людини, пріоритетності норм міжнародного права, верховенства права та ін. Оскільки ці принципи є загальноправовими, то можна твердити, що вони виступають основою обох правових інститутів - i судочинства, і медіації - і забезпечують їх сумірність.

Якщо говорити про галузеві/міжгалузеві принципи, то вони більшою мірою стосуються т.зв. присудової медіації, що передбачена, зокрема, главою 4 розділу ІІІ Цивільного процесуального кодексу України (Цивільний процесуальний кодекс, 2004). Дослідники підкреслюють, що «досудове врегулювання спорів за участю судді підпорядковане вимогам процесуальної форми та проводиться кваліфікованим юристом - суддею. При чому, якщо посередник-медіатор лише сприяє комунікації сторін і останні самостійно повинні визначити найбільш оптимальне для них рішення, посередник-суддя може запропонувати сторонам можливий шлях мирного врегулювання спору (Бондаренко-Зелінська, 2018: 65). Отже, присудова медіація як частина цивільного процесу базується на таких засадах, як незалежність суддів, процесуальна рівність сторін перед законом, диспозитивність, безпосередність дослідження доказів, дотримання процесуальної форми тощо.

Третю групу принципів медіації формують ідеї, які визначають специфіку цієї форми розв'язання спорів (конфліктів), у зв'язку з чим пропонуємо іменувати їх спеціальними. Услід іншим дослідникам, на основі аналізу зарубіжного досвіду у сфері медіації та відповідних рамкових міжнародних документів, вважаємо за доцільне виокремити такі спеціальні принципи медіації, як доступність, добровільність, рівність сторін, нейтральність медіатора, конфіденційність. Принцип доступності означає, що суб'єкти права мають доступ до такого альтернативного способу вирішення спорів, при цьому така можливість передбачена законодавством. Як уже зазначалося, можливість будь-якими не забороненими законом засобами захищати свої права і свободи від порушень і протиправних посягань закріплена у ч. 5 ст. 55 Конституції України. Окрім того, у ст. 124 Основного Закону України міститься норма, яка встановлює, що законом може бути визначений обов'язковий досудовий порядок урегулювання спору. Це положення стосується, зокрема, медіації. Однак вимога обов'язкового досудового врегулювання спору певною мірою суперечить принципу добровільності медіації, згідно з яким процедура медіації може розпочатися і припинитися виключно за волею сторін. Важливе значення має принцип рівності сторін, відмінний від принципу процесуальної рівноправності у цивільному судочинстві тим, що сторони медіаційної процедури мають не просто рівні, а однакові права. На цьому цілком слушно наголошує 3. В. Красіловська (Красіловська, 2017: 35). Принцип конфіденційності передбачає нерозголошення інформації, що стосується медіації, однак тут можуть бути винятки - у разі врегулювання шляхом медіації публічно-правових спорів забезпечити повну конфіденційність не уявляється можливим. Окрім того, дослідники підкреслюють важливість закріплення на

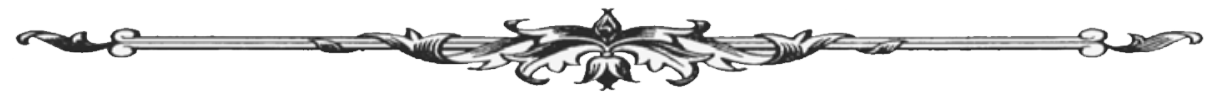


законодавчому рівні «імунітету» для медіатора (Боженко, 2018: 145), тобто заборони допитувати медіатора щодо інформації, яка стала йому відома під час здійснення медіації, а також щодо самої процедури, неможливості медіатора свідчити у суді у разі, якщо сторони не досягли згоди під час медіації і справа передана на судовий розгляд. Принцип нейтральності медіатора означає, що він має бути незалежним і неупередженим. У своїй діяльності медіатор незалежний від будь-якої зі сторін та будь-яких органів державної влади. Неупередженість медіатора передбачає його однакове ставлення до сторін спору.

На думку Ю. Д. Притики, медіатор може відмовитись від ведення процедури (самовідвід) у випадку появи обставин, що обумовлюють його зацікавленість у вирішенні справи на користь однієї із сторін (Притика, 2010: 91). Вважаємо, що в такому разі самовідвід медіатора має бути обов'язковим.

Узагальнюючи викладене вище, принципами медіації слід вважати ті засади, які формують основу процедури медіації і забезпечують ефективне й взаємоприйнятне розв'язання конфлікту самими його сторонами за участю нейтральної особи - медіатора.

Висновки. Резюмуючи, варто підкреслити, що медіація та судочинство є суміжними правовими інститутами, що характеризуються низкою як спільних, так і відмінних ознак. Передовсім це зумовлено тим, що системи принципів, які виступають основою цих правових інститутів, не є тотожними. Оскільки в Україні медіація поки що не отримала необхідної нормативно-правової бази, відсутнє й нормативне закріплення ії системи принципів. I, навпаки, система основних засад судочинства відображена в Конституції України, Законі України «Про судоустрій і статус суддів» та галузевому процесуальному законодавстві. Однак відсутність нормативного вираження принципів медіації не може бути перешкодою для функціонування цього інституту. Поділяючи поширену в юридичній науці думку про виокремлення загальноправових, міжгалузевих та конкретно-правових принципів медіації, вважаємо, що останню групу принципів варто іменувати спеціальними, оскільки саме вони зумовлюють специфіку цього правового інституту. До таких принципів належать доступність, добровільність, рівність сторін, нейтральність медіатора, конфіденційність. Саме ці принципи вирішальною мірою сприяють досягненню мети медіації - прийняття рішення, яке задовольняє інтереси сторін спору та усуває конфлікт між ними.

\section{Список використаних джерел:}

1. Боженко Н. В. Адміністративно-правове забезпечення медіації як способу вирішення адміністративних спорів : дис. ... канд. юрид. наук : 12.00.07. Запоріжжя, 2018. 214 с.

2. Бондаренко-Зелінська Н. Л. Врегулювання спору за участю судді: проблеми та перспективи застосування. Університетські наукові записки. 2018. № 67-68. С. 62-70.

3. Городовенко А. Загальні засади конституційної модернізації судової системи як об’ єктивного суспільно-правового процесу. Актуальні проблеми правознавства. 2018. Вип. 1(13). С. 73-79.

4. Грищук О. Принципи права: філософсько-правовий вимір. Вісник Львівського університету. Серія юридична. 2015. Вип. 61. С. 16-23.

5. Зайчук О. В. Принципи права в контексті розвитку загальної теорії держави і права. Альманах права. 2012. Вип. 3. С. 22-28.

6. Запара С. І. Поняття медіації та особливості іiі становлення в Україні та світі. Порівняльно-аналітичне право. 2015. № 3. С. 86-88.

7. Конвенція про захист прав людини та основоположних свобод: міжнародний документ від 04.11.1950. URL: https://www.echr.coe.int/Documents/Convention_UKR.pdf.

8. Конституція України: Закон України від 28.06.1996 p. URL: http://zakon2.rada.gov. ua/laws $/ 254 \%$ D0\%BA/96-\%D0\%B2\%D1\%80.

9. Красіловська 3. В. Становлення інституту медіації в системі публічного управління: теоретико-правовий аспект : дис. ... канд. юрид. наук : 25.00.01. Одеса, 2017. 221 с.

10.Кримінальний процесуальний кодекс України від 13.04.2012 № 4651-VI. URL: https://zakon.rada.gov.ua/laws/card/4651-1713.04.2012.

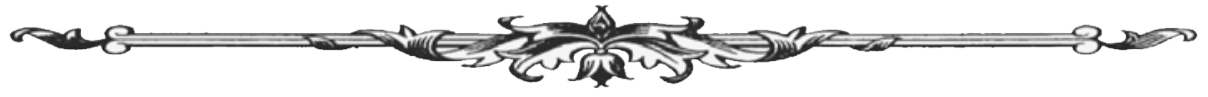


11. Кримінальний процесуальний кодекс України. Науково-практичний коментар : у 2 т. Т. 1 / О. М. Бандурка та ін. Харків : Право, 2012. 768 с.

12. Міліціанов Р. В. Класифікація конституційних засад судочинства в Україні. Науковий вісник Херсонського державного університету. Серія «Юридичні науки». 2014. Вип. 5. T. 1. С. 107-111.

13. Притика Ю. Д. Зміст та класифікація принципів медіації. Бюлетень Міністерства юстиичї України. 2010. № 10. С. 86-92.

14.Про судоустрій і статус суддів: Закон України від 02.06.2016 № 1402-VIII. URL: https://zakon.rada.gov.ua/laws/card/1402-19.

15. Теліпко В. Е. науково-практичний коментар Конституції України / За ред. Мусіяки В. Л. Київ : Центр учбової літератури, 2011. 544 с.

16. Цивільний процесуальний кодекс України від 18.03.2004 № 1618-IV URL: https://zakon.rada.gov.ua/laws/card/1618-15.

КОРНІЕНКО М. В., доктор юридичних наук, професор, перший проректор (Дніпровський гуманітарний університет)

СокоЛ Д. О., студент II курсу магістратури юридичного факультету (Дніпровський гуманітарний університет)

УДК 343.2

DOI https://doi.org/10.32842/2078-3736-2019-6-1-6

\section{ДЕЯКІ ПИТАННЯ НОРМАТИВНО-ПРАВОВОЇ РЕГЛАМЕНТАЦЇ̈ ПРАВА НА ВІЛЬНИЙ ДОСТУП ДО ВОГНЕПАЛЬНОЇ ЗБРОЇ}

У статті досліджуються окремі проблемні питання нормативно-правової регламентації права на вільний доступ до вогнепальної зброї, з'ясовується його природа й місце у вітчизняному законодавстві. Адже проблеми забезпечення різноманітних прав і свобод громадян України на перехідному етапі від тоталітарного російського впливу до засад правової європейської держави, в умовах російсько-терористичної агресії вимагають по-новому поглянути на засади та правовий інструментарій обігу й застосування зброї в Україні. Провідне місце в системі правових норм, за допомогою яких здійснюється забезпечення обігу й застосування зброї, відведено нормам адміністративного та кримінального права, що регулюють юридичний режим обігу зброї, порядок її придбання, зберігання, носіння i, як крайній засіб, - застосування 3 метою захисту життя та здоров’я громадян, забезпечення територіальної цілісності України від загрози з боку російсько-терористичних військових формувань. Значної актуальності цьому дослідженню додає проведення Збройними Силами України,

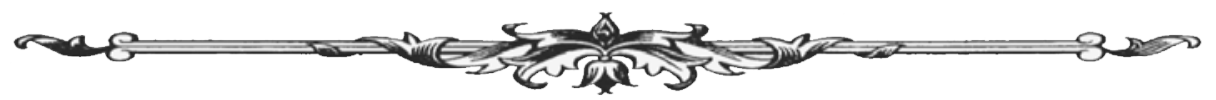

